\title{
Holocene trends in the foraminifer record from the Norwegian Sea and the North Atlantic Ocean
}

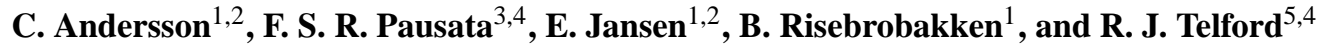 \\ ${ }^{1}$ UNI Bjerknes Centre, Bergen, Norway \\ ${ }^{2}$ Department of Earth Science, University of Bergen, Bergen, Norway \\ ${ }^{3}$ Geophysical Institute, University of Bergen, Bergen, Norway \\ ${ }^{4}$ Bjerknes Centre for Climate Research, Bergen, Norway \\ ${ }^{5}$ Department of Biology, University of Bergen, Bergen, Norway
}

Received: 26 June 2009 - Published in Clim. Past Discuss.: 30 July 2009

Revised: 1 March 2010 - Accepted: 17 March 2010 - Published: 30 March 2010

\begin{abstract}
The early to mid-Holocene thermal optimum is a well-known feature in a wide variety of paleoclimate archives from the Northern Hemisphere. Reconstructed summer temperature anomalies from across northern Europe show a clear maximum around 6000 years before present (6 ka). For the marine realm, Holocene trends in sea-surface temperature reconstructions for the North Atlantic and Norwegian Sea do not exhibit a consistent pattern of early to midHolocene warmth. Sea-surface temperature records based on alkenones and diatoms generally show the existence of a warm early to mid-Holocene optimum. In contrast, several foraminifer and radiolarian based temperature records from the North Atlantic and Norwegian Sea show a cool midHolocene anomaly and a trend towards warmer temperatures in the late Holocene. In this paper, we revisit the foraminifer record from the Vøring Plateau in the Norwegian Sea. We also compare this record with published foraminifer based temperature reconstructions from the North Atlantic and with modelled (CCSM3) upper ocean temperatures. Model results indicate that while the seasonal summer warming of the seasurface was stronger during the mid-Holocene, sub-surface depths experienced a cooling. This hydrographic setting can explain the discrepancies between the Holocene trends exhibited by phytoplankton and zooplankton based temperature proxy records.
\end{abstract}

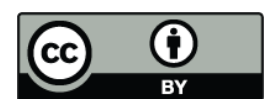

Correspondence to: C. Andersson (carin.andersson@uni.no)

\section{Introduction}

A prominent feature in a wide variety of paleoclimate archives from the Northern Hemisphere is the existence of a period of Holocene warmth, the so-called Holocene thermal maximum (e.g. Kaufmann et al., 2004) or early to midHolocene optimum (e.g. Jansen et al., 2008). The length of the Early to mid-Holocene optimum varies in literature. In its broadest sense the period between $11000-5000$ yrs before present (11-5 ka) corresponds to a period of relative warmth at high and middle latitudes of the Northern Hemisphere (Renssen et al., 2009). It is clear that proxy based reconstructions show differences in both timing and magnitude of peak Holocene warmth (Kaufmann et al., 2004; Renssen, et al., 2009). From the western Arctic $\left(0-180^{\circ} \mathrm{W}\right)$ there are clear evidence of an average warming of $1.6^{\circ} \mathrm{C}$ based on a large compilation of different proxy records, terrestrial, ice-core and marine. However, northwest Canada experienced a thermal optimum between $11-9 \mathrm{ka}$, about 4000 years prior to the thermal optimum in northeast Canada. The delay in warming in this region was likely caused by influences of the Laurentide ice-sheet. In other regions, which were dominated by orbital forcing, the thermal maximum occurred earlier (Kaufmann et al., 2004; Renssen et al., 2009). Reconstructed summer temperature anomalies from across a wide area of northern Europe show a clear maximum around $6 \mathrm{ka}$ (Davis et al., 2003). For Scandinavia there are considerable evidence for a mid-Holocene thermal optimum (Davis et al., 2003). For the marine realm, Holocene trends in sea-surface temperature (SST) reconstructions for the North Atlantic and Norwegian Sea do not exhibit a consistent pattern of early to midHolocene warmth. Besides differences in the reconstructions that originate from local differences in oceanographic

Published by Copernicus Publications on behalf of the European Geosciences Union. 


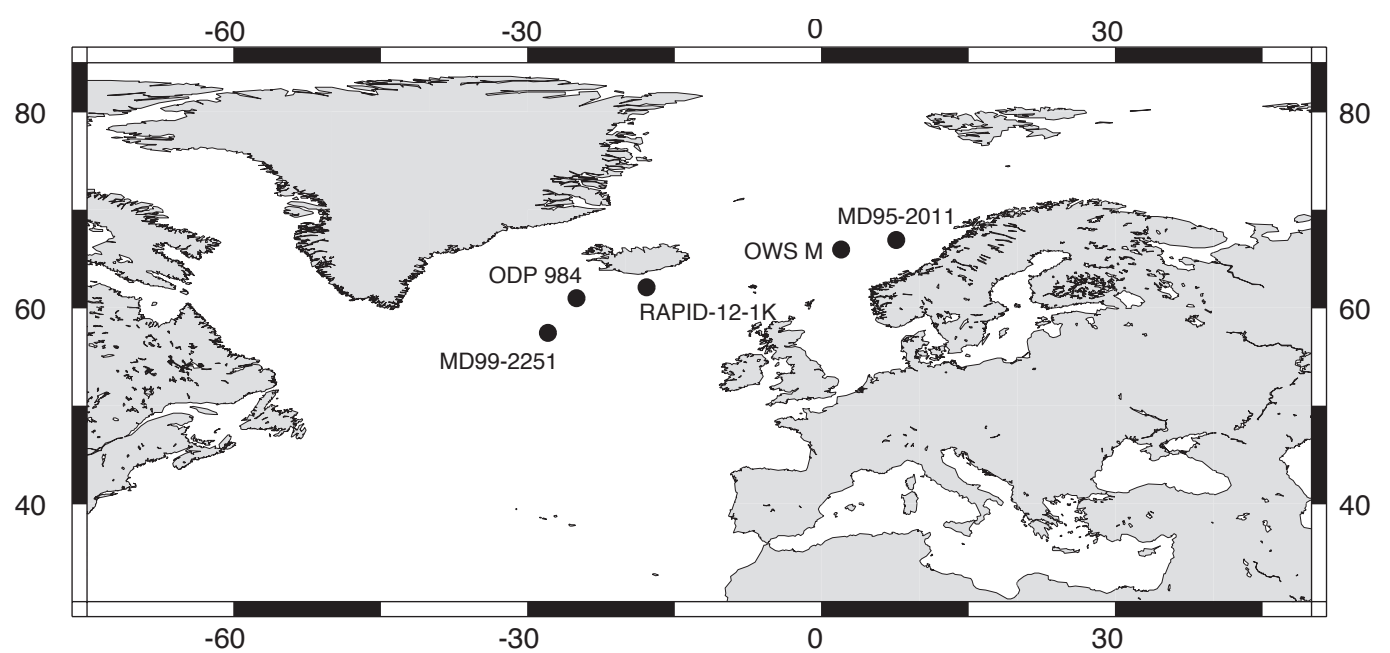

Fig. 1. Map showing the location of cores MD95-2011, MD99-2251, ODP 984 and RAPiD-12-1K. The position of Ocean Weather Station (OWS) Mike is also shown.

settings between coring locations, there are results that point towards proxy- related differences between the reconstructions. Proxies derived from photosynthesizing organisms, i.e. diatom and alkenone based SST reconstructions do often exhibit an early to mid-Holocene optimum, whereas zooplankton-based SST reconstructions do not. A compilation of North Atlantic SST proxy data from alkenones (Kim et al., 2004a, b) and foraminifers (transfer functions SST estimates) (Andersson, 2005) for $6 \mathrm{ka}$ also show that the $6 \mathrm{ka}$ anomaly from these two SST proxies is quite different. The $6 \mathrm{ka}$ anomalies from alkenone reconstructions are generally positive, i.e. $6 \mathrm{ka}$ were warmer than the pre-industrial period, and there is also an indication of a polar amplification during the $6 \mathrm{ka}$ anomaly (Marchal et al., 2002; Rimbu et al., 2003; Kim et al., 2004c; Lorenz et al., 2006). In comparison, the North Atlantic $6 \mathrm{ka}$ anomalies reconstructed using transfer function SST estimates from planktic foraminifers are not consistently positive and do not display any polar amplification (Andersson, 2005). One explanation for this is that there were a different evolution of surface ocean temperatures between the very sea-surface, occupied by phytoplankton, and waters closer to the thermocline, depths occupied by zooplankton throughout the Holocene in the North Atlantic and Norwegian Sea (e.g. Jansen et al., 2008). Hence, differences in depth habitat between zoo- and phytoplankton are responsible for the differences in terms of presence/absence of a Early to mid-Holocene optimum and the different long-term trends in the SST reconstructions.

In this paper we revisit the Holocene record from the Norwegian Sea and compare this record to more recently published data from the North Atlantic in order to explore the trends in the foraminifer record in more detail. We also use model results for $6 \mathrm{ka}$ to look into the differences between reconstructed phytoplankton-based and zooplanktonbased SST estimates for the Norwegian Sea and the northern North Atlantic.

\section{Material and methods}

Core MD95-2011 is located under the easternmost limb of the warm Norwegian Atlantic Current (the northern continuation of the North Atlantic Current; NAC). The site was originally cored during IMAGES campaign MD101, and a $17.49 \mathrm{~m}$ long core was recovered from $1048 \mathrm{~m}$ water depth $\left(66.97^{\circ} \mathrm{N}, 7.64^{\circ} \mathrm{E}\right)$ (Fig. 1) using a giant piston corer (CALYPSO). Due to overpenetration of the giant piston corer, a box core, JM97-948/2A, was later taken at the same position to sample the surface sediments lost during the piston coring. An age-depth model for the Holocene was developed using a combination of ${ }^{210} \mathrm{~Pb}$-dating and accelerator mass spectrometer (AMS) radiocarbon dating techniques (Andersson et al., 2003; Risebrobakken et al., 2003). Multiple proxies for surface-ocean reconstructions have been developed for MD95-2011. Stable oxygen isotope records from Neogloboquadrina pachyderma (dex) and Neogloboquadrina pachyderma (sin) were published by Andersson et al. (2003) and Risebrobakken et al. (2003). Census counts and foraminifer-based SST estimates for the Holocene are also published (Andersson et al., 2003; Risebrobakken et al., 2003). The foraminifer SST estimates were originally calculated using the modern analog technique. We have used the same foraminifer census counts and recalculated the foraminifer SST estimates using the Maximum Likelihood technique (ter Braak and Looman, 1986; ter Braak and Prentice, 1989; ter Braak and van Dam, 1989). Modern SST values for $10 \mathrm{~m}$ water depth during summer (July, August, September) for the calibration dataset were taken from the World Ocean Atlas version 2 (WOA, 1998). In addition to the foraminifer-based record, SST estimates for MD95-2011 are available from alkenones (Calvo et al., 2002; Jansen et al., 2008), diatoms (Birks et al., 2002; Andersen et al., 2004), and radiolarians (Dolven et al., 2002). Here, we compare results from MD95-2011 with newly published foraminifer 
SST records from the northern North Atlantic. The locations for sites discussed in this paper are shown in Fig. 1. Genotype studies have suggested a renaming of $N$. pachyderma (dex) to Neogloquadrina incompta when the percentage of right coiling forms is between 3 and 97\% (Darling et al., 2006). In this study we continue to use N. pachyderma (dex) to easily draw cross-references to the already published data from the Norwegian Sea and the North Atlantic discussed in this paper.

In this study we compare temperature proxy reconstructions with model output that belongs to the Paleoclimate Modelling Intercomparison Project Phase II (PMIP2/MOTIF). The model used is the Community Climate System Model 3.0 (CCSM3). The horizontal resolution in the ocean has a nominal grid spacing of $0.4^{\circ} \times 1.1^{\circ}$ (lat $\times$ lon). The ocean model has 40 levels with finer resolution near the surface (15 levels in the first $250 \mathrm{~m})$. Boundary conditions for the pre-industrial (PI, $1750 \mathrm{AD}$ ) and mid-Holocene (MH, $6 \mathrm{ka}$ ) follow the protocol established by PMIP2 (http: //pmip2.lsce.ipsl.fr). In the PI simulations, the orbital configuration is set to $1950 \mathrm{AD}$ values, the greenhouse gases correspond to $1750 \mathrm{AD}$, and vegetation is suggested to represent present day distribution. In the MH simulations, the orbital configuration is set to $6 \mathrm{ka}$, when the summer insolation was much higher in the Northern Hemisphere, whereas the winter insolation was lower compared to the PI; the vegetation, the ice-sheet extent and greenhouse gas concentrations (except for the methane that are lower) are the same as in the PI. 100 years of monthly post-spin up ocean potential temperature data for the Atlantic basin $\left(30^{\circ}-85^{\circ} \mathrm{N} / 90^{\circ} \mathrm{W}-45^{\circ} \mathrm{E}\right)$ are analyzed for both the MH and PI simulations. For further details see Braconnot et al. (2007). Details of the CCSM3 ocean component can be found in Smith and Gent (2004). The sea ice component of CCSM3 is described in detail by Holland et al. (2006). The polar climate of the twentieth and twenty-first centuries in this model is discussed in Meehl et al. (2006) and Holland et al. (2006). Comparisons of ocean temperatures at different seasons and depths between CCSM3 and observations from World Ocean Atlas 98, are presented in Figs. 2, 3, 4 , and 5 .

We analyze North Atlantic sea-surface (10 m depth) and sub-surface ( $100 \mathrm{~m}$ depth) ocean potential temperature for winter (from January to March, JFM), summer (from July to September, JAS) and annual average in both climate states. We also consider the vertical profile for the four proxy locations.

\section{Results and discussion}

\subsection{Holocene SSTs in the Norwegian Sea}

The record from the Vøring Plateau (MD95-2011) is among the Holocene records with the highest temporal resolution from the Norwegian Sea. From the multiple SST proxy records available for MD95-2011, it is clear that there is

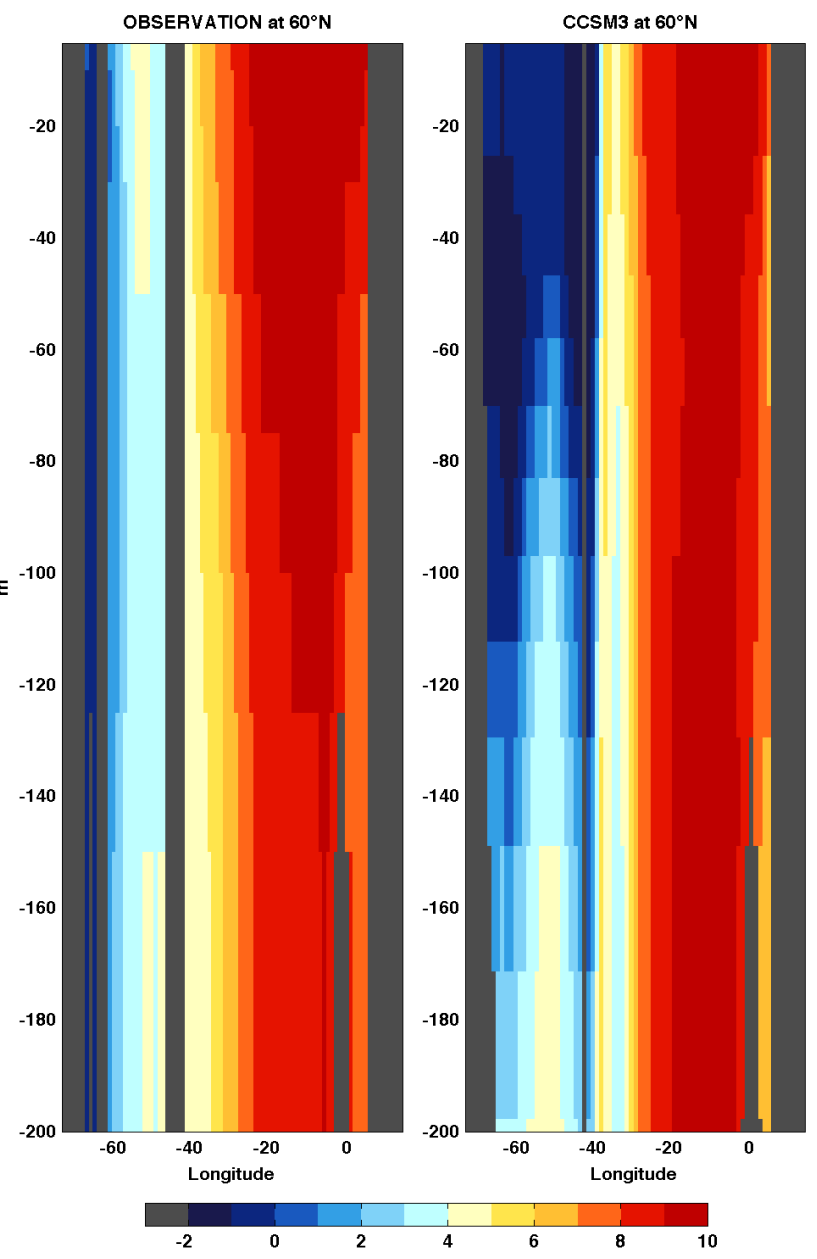

Fig. 2. Comparisons of annual temperature between CCSM3 and WOA98 at a transect $60^{\circ} \mathrm{N}$. NODC WOA98 data were provided by the NOAA/OAR/ESRL PSD, Boulder, Colorado, USA, from their Web site at http://www.esrl.noaa.gov/psd/.

a distinct difference between SST estimates derived from phytoplankton based records, i.e. the diatom and alkenone records, and zooplankton based records (foraminifers and radiolarians) (Fig. 6). Most phytoplankton species of coccoliths and diatoms thrive in the upper photic zone corresponding to the upper $50 \mathrm{~m}$ and bloom when nutrients and light conditions in the upper mixed layer are favourable (Abrantes, 2007; Flores and Sierro, 2007). Zooplankton assemblages, however, like those from foraminifers and radiolarians, contain a combination of species with wide preferences in depth habitat. Foraminifer assemblages often consist of both nearsurface $(0-50 \mathrm{~m})$ species and more deep-dwelling $(>100 \mathrm{~m})$ species (Dowsett, 2007). Radiolarians have an even wider range of depth habitats going from the upper few meters of the surface layer to abyssal depths (Lazarus, 2005). This means that SST estimates derived from foraminifers and radiolarians contain an integration of environmental conditions over a certain depth range. 


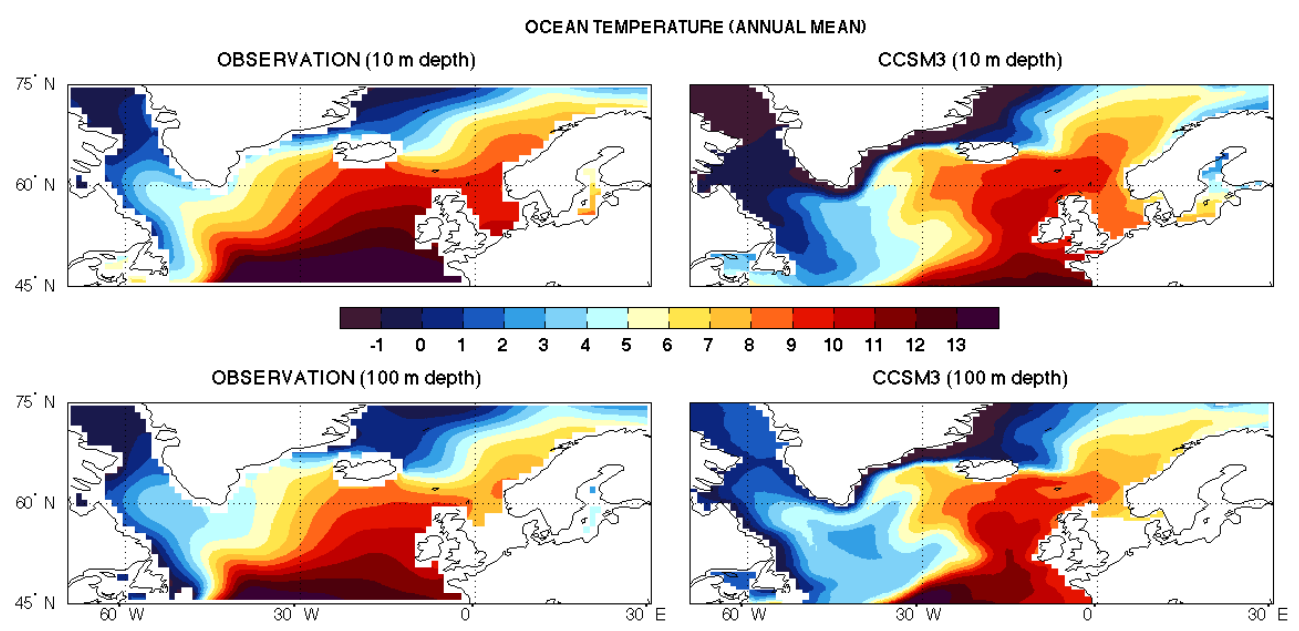

Fig. 3. Comparison of the mean annual temperature at $10 \mathrm{~m}$ and $100 \mathrm{~m}$ between CCSM 3 and WOA98. NODC WOA98 data were provided by the NOAA/OAR/ESRL PSD, Boulder, Colorado, USA, from their Web site at http://www.esrl.noaa.gov/psd/.

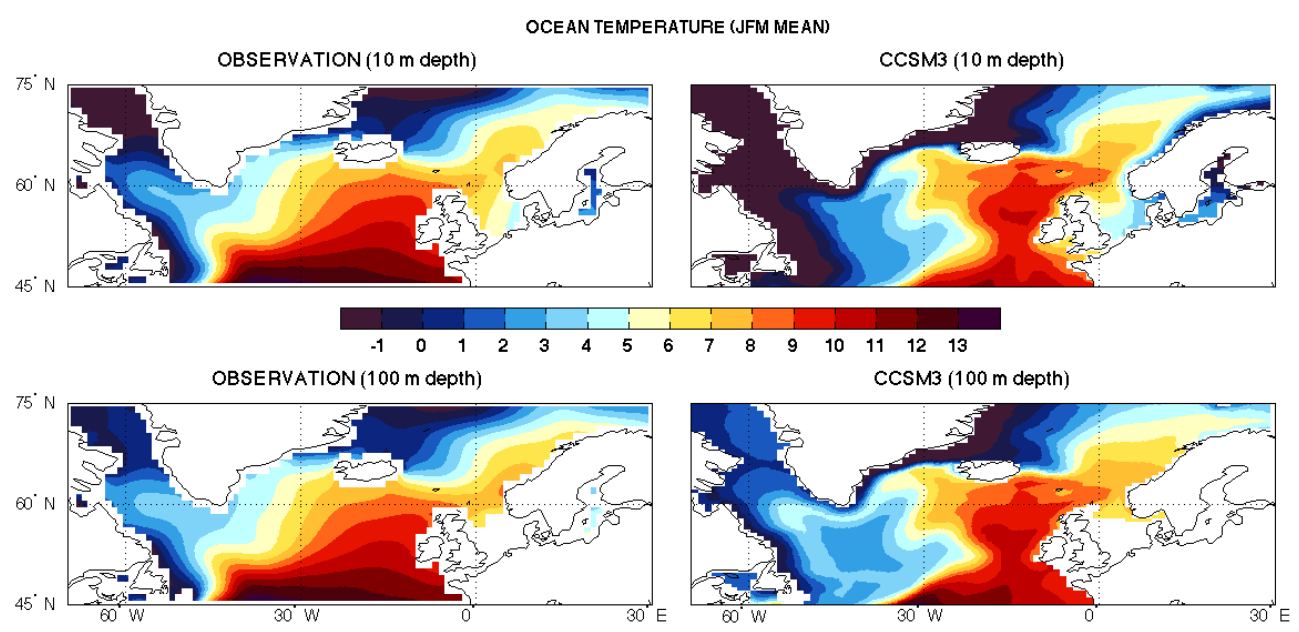

Fig. 4. Comparison of the mean January, February, and March temperature at $10 \mathrm{~m}$ and $100 \mathrm{~m}$ between CCSM 3 and WOA98. NODC WOA98 data were provided by the NOAA/OAR/ESRL PSD, Boulder, Colorado, USA, from their Web site at http://www.esrl.noaa.gov/psd/.

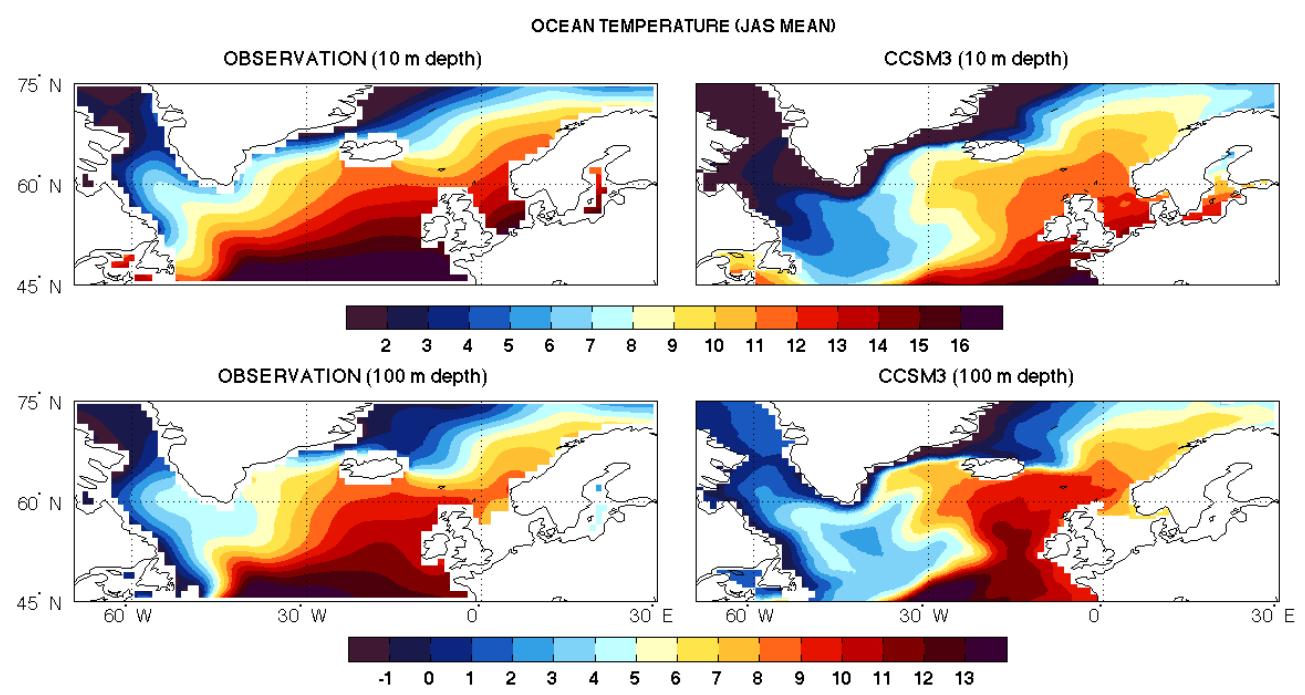

Fig. 5. Comparison of the mean July, August, and September temperature at $10 \mathrm{~m}$ and $100 \mathrm{~m}$ between CCSM3 and WOA98. NODC WOA98 data were provided by the NOAA/OAR/ESRL PSD, Boulder, Colorado, USA, from their Web site at http://www.esrl.noaa.gov/psd/. 
The Holocene trends of the diatom and alkenone SSTs correspond with the trend of decreasing summer insolation throughout the Holocene. These data show a clear trend of decreasing summer temperatures since the midHolocene and indicate that summer temperatures were up to $2{ }^{\circ} \mathrm{C}$ higher in the mid-Holocene in northern Scandinavia compared to the present (Fig. $6 \mathrm{~b}$ and c). A similar longterm trend of decreasing temperature is also often seen in terrestrial temperature reconstructions such as the pollen-based July SST reconstruction from northern Finland (Seppä and Birks (2001) (Fig. 6a). The zooplankton-based records do not display an early to mid-Holocene warmth and declining temperatures towards the late Holocene. The transfer function based summer SST reconstruction from radiolarians (Dolven et al., 2002) (Fig. 6e) and foraminifers (Andersson et al., 2003; Risebrobakken et al., 2003) (Fig. 6d) exhibits trends towards slightly higher temperatures towards the late Holocene, in addition to a multi-decadal type of variability with several cooling events throughout the records. Kucera et al. (2005) point out that a level of disagreement between different SST proxies must be expected because each approach reflects different past environmental conditions. At the Vøring Plataeu the observed difference in SST trends between the two plankton types is so large that it seems likely that these two proxies actually record quite different environmental conditions due to different ecological preferences of phyto-versus zooplankton. This difference is also too large to be the result of any methodological biases coming from different SST estimation techniques.

The Holocene foraminifer fauna in the eastern Norwegian Sea is dominated by $N$. pachyderma $(\sin ), N$. pachyderma (dex), and Globigerina quinqueloba. Simstich et al. (2003) found that in the Norwegian Current $N$. pachyderma $(\sin )$ calcify at depth below the pycnocline $(70-250 \mathrm{~m})$ where temperatures are generally lower by $2-3^{\circ} \mathrm{C}$ compared to the seasurface. In polar waters the depth habitat of $N$. pachyderma (sin) appears to depend on the vertical stratification (Kohfeld et al., 1996). Only in areas with a deep $(>300 \mathrm{~m})$ mixed layer and minimal seasonal temperature changes would $N$. pachyderma $(\sin )$ record surface ocean conditions. Thus, it is likely that $N$. pachyderma (sin) is a deeper-dwelling species that calcify below the thermocline. Based on the offset between N. pachyderma (dex) and N. pachyderma $(\sin )$ in the stable oxygen isotope records (Risebrobakken et al., 2003) and the $\mathrm{Mg} / \mathrm{Ca}$ records (Nyland et al., 2005) it seems likely that $N$. pachyderma (dex) calcify at shallower depth (and/or during a warmer part of the year) relative to N. pachyderma $(\sin )$. North of Iceland $N$. pachyderma (dex) calcifies throughout the year at water depth between 30 and $40 \mathrm{~m}$ (Osterman et al., 1999). However, North of Iceland N. pachyderma ( $\sin )$ calcify at the same depth as N. pachyderma (dex), which makes it open to discussion if the depth habitat of $N$. pachyderma (dex) is the same in the eastern Norwegian Sea. Ottens (1992) suggests that $N$. pachyderma (dex) calcifies at depth below $75 \mathrm{~m}$ in the northeast Atlantic, and
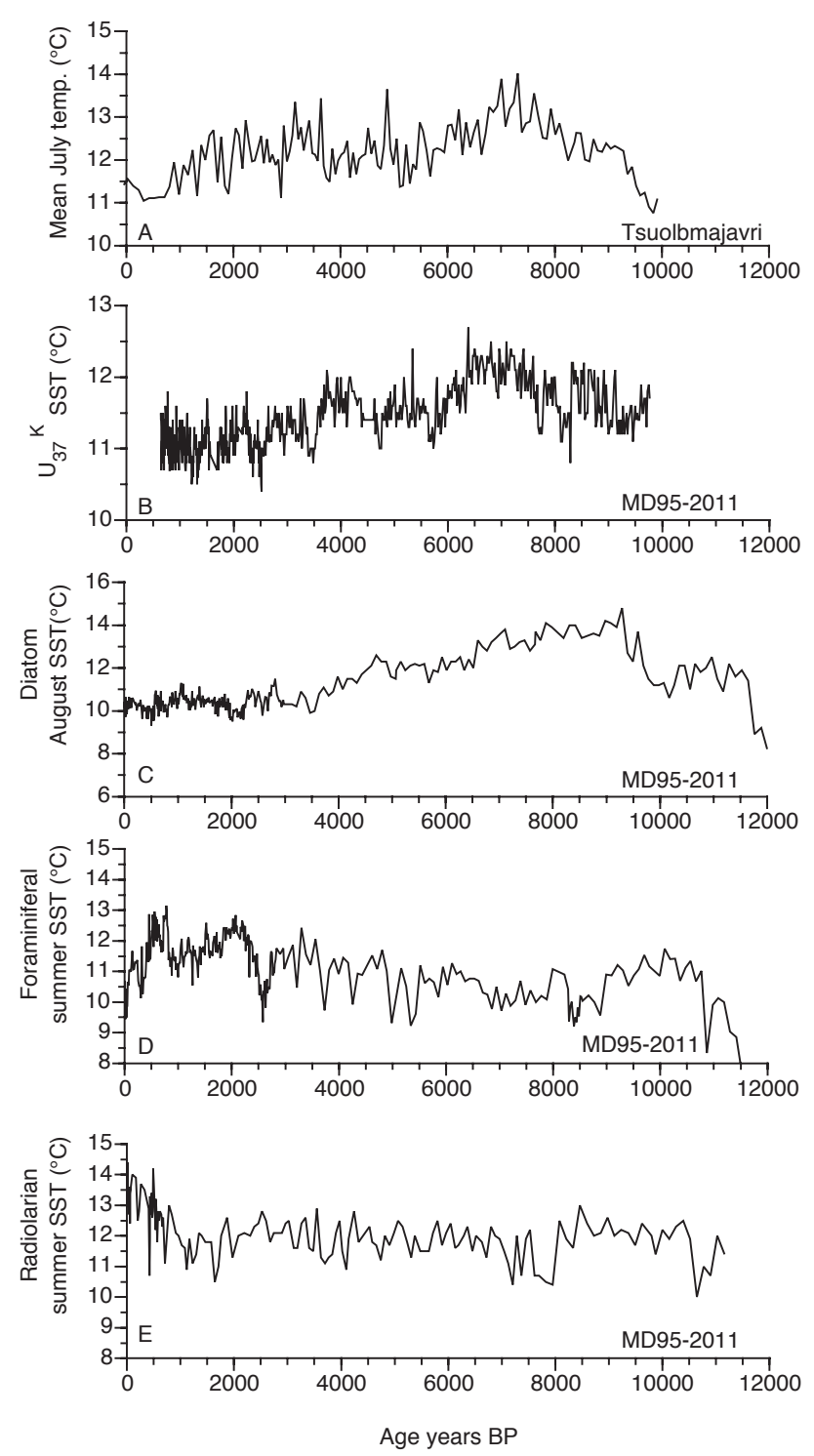

Fig. 6. (A) Mean July temperature based on pollen from Tsuolbmajavri, Finland (Seppä and Birks, 2001). (B) Alkenone derived seasurface temperatures from the Vøring Plateau (MD95-2011) (Calvo et al., 2002; Jansen et al., 2008). (C) Diatom-based sea-surface August temperature estimates from MD95-2011 (Birks et al., 2002). (D) Foraminiferal-based transfer function sea-surface temperature estimates for summer (JAS) for MD95-2011 (Andersson et al., 2003; Risebrobakken et al., 2003; this study). (E) Radiolarianbased transfer function sea-surface summer temperature estimates for MD95-2011 (Dolven et al., 2002).

according to Simstich et al. (2003) the calcification depth of G. quinqueloba is between 25 and $75 \mathrm{~m}$, matching the depth of the pycnocline. Recently, Fraile et al. (2009) used a global foraminifer model (PLAFOM) to evaluate the seasonal imprint on the sedimentary record. They found that for $N$. pachyderma $(\sin ), N$. pachyderma $(\operatorname{dex})$ and Globigerina bulloides the difference between the predicted value and the 
annual mean temperature was positive for all three species, indicating a bias towards summer temperatures for these species. Berstad et al. (2003) also suggested that calcification of $N$. pachyderma (dex) occurs during summer (JAS) in the eastern Norwegian Sea.

Other foraminifer records from the eastern Norwegian Sea also share the Holocene trends in the foraminifer record SST from the Vøring Plateau. Hald et al. (2007) published a comparison between six published surface temperature proxy records, including MD95-2011, along a S-N transect on the Norwegian-Continental margin. This comparison shows that records from the southern part of the transect $\left(60-69^{\circ} \mathrm{N}\right)$ have stable SSTs or slightly increasing SSTs throughout the Holocene. The northernmost records $\left(72-77.4^{\circ} \mathrm{N}\right)$ display a pronounced warming in the early Holocene followed by a long-term SST decrease and a subsequent weak warming in the latest Holocene. The different trends between the southern and northern transects were suggested to result from a polar amplification of early Holocene warmth for the northernmost records.

The lack of an early Holocene warm period in the southeastern Norwegian Sea was suggested to reflect the influence of cooler subsurface water masses possibly related to increased seasonality caused by orbital forcing and increased stratification due to freshening (Hald et al., 2007). Risebrobakken et al. (2003) suggested that the long-term Holocene trend, as seen in the foraminifer record at site MD95-2011, is related to horizontal migration of the Arctic water/Atlantic water interface (Arctic Front). The oceanography of the Vøring Plateau is governed by the presence of two water masses: the inflowing warm and saline North Atlantic surface water and the less saline and cooler Arctic intermediate water mass (see Risebrobakken, 2003, and references therein). Risebrobakken et al. (2003) suggested that the Arctic front and Arctic water masses were closer to the site MD95-2011 during the early and mid-Holocene than during the late Holocene. The stronger influence of Arctic water during the early Holocene would result in cooler sub-surface temperatures that would be recorded by planktic foraminifers. This interpretation was based on two observations in the planktic record. Firstly, in Arctic water there is no difference between the stable oxygen isotope composition in $N$. pachyderma $(\sin )$ and N. pachyderma (dex), while the differences increase towards east in The Nordic Seas (Johannessen, 1992). Hence, the varying stable oxygen isotope contrast between $N$. pachyderma (dex.) and $N$. pachyderma $(\sin )$ can be used as an indicator of horizontal migration of the Arctic water/Atlantic water interface. In MD95-2011 $\Delta \delta^{18} \mathrm{O}$ values of $N$. pachyderma (dex) and $N$. pachyderma (sin) is lower during the early and mid-Holocene relative to the late Holocene, indicating an eastward migration of the Arctic Front. Secondly, high relative abundances of $G$. quinqueloba, a species strongly related to the Arctic Front (Johannessen et al., 1994), between 8-4 ka also indicate a more eastward location of the boundary between Arctic and
Atlantic waters before $4 \mathrm{ka}$. During recent decades, subsurface eastward migration of Arctic waters has been caused by an increase in the strength of the westerlies (Blindheim et al., 2000). Stronger influence of sub-surface Arctic water could possibly also explain the observed difference between SSTs derived from phytoplankton and zooplankton at the Vøring Plateau. The relatively deeper dwelling zooplankton could have experienced cooler sub-surface conditions in the early- and mid-Holocene compared to the late Holocene.

According to Jansen et al. (2008) the difference between different SST proxies (basically, between diatom and alkenones SSTs and foraminifer and radiolarian SSTs) is due to the seasonality of orbital forcing, the habitat of the different biological proxies, and the vertical structure of the high-latitude ocean. A positive thermal anomaly during the summer season and a small negative anomaly during winter gave rise to enhanced seasonality during the early to midHolocene. The observed difference between zooplankton and phytoplankton SSTs can be explained as a response to the seasonality of the forcing. The long-term orbital trends during the Holocene could be reflected in both the phytoplankton SST records (summer insolation) and zooplankton records (winter insolation). Jansen et al. (2008) suggests that foraminifera living at or around the thermocline experience temperatures unrelated to the summer season, which would explain the observed difference between zooplankton and phytoplankton SST records. At Ocean weather Station Mike (Østerhus et al., 1996) (Figs. 1 and 7), there is a strong summer warming and stratification of the sea-surface. At $100 \mathrm{~m}$ water depth mixing occurs during winter when the seasonal thermocline breaks down. Hence, species living at this depth would record a signal related to winter-ventilation. However, the seasonal variability is negligible below the thermocline, which means that all seasons are close to the annual mean temperature at this depth. As a result, although the maximum production of foraminifera in general occurs during spring and/or summer, deeper-dwelling species could record temperatures more comparable to the annual mean. In a modelling study of the upper ocean SST evolution and its response to orbital forcing through the Holocene, Liu et al. (2003) found negative mean annual temperature anomalies in the early and mid-Holocene at 100-300 m water depth for the mid-latitudes of the North Atlantic. However, this modelling experiment does not give any insight to the surface and sub-surface conditions of the Norwegian Sea.

\subsection{North Atlantic versus Norwegian Sea SST record}

SST records from the subpolar North Atlantic also share the observed trend of a warming since the early and midHolocene seen in the foraminifer SST records from the eastern Norwegian Sea. A recently published $\mathrm{Mg} / \mathrm{Ca}$ SST record from MD99-2251 (Farmer et al., 2008) (Figs. 1 and 8) displays many similarities to the foraminifer faunal SST record from MD95-2011 for much of the last 9.5 ka. Both the 
overall trends as well as absolute SST values agree well between the two records. As pointed out by Farmer et al. (2008), mid-Holocene temperatures in MD99-2251 are cooler $\left(1.5^{\circ} \mathrm{C}\right)$ than the average temperature for the last $3.5 \mathrm{ka}\left(10.1^{\circ} \mathrm{C}\right.$ at $6 \mathrm{ka}$ relative to $11.6^{\circ} \mathrm{C}$ for the last $\left.3.5 \mathrm{ka}\right)$. To be consistent with mid-Holocene paleomodel results we define the mid-Holocene to be centred at $6 \mathrm{ka}$ and calculated averages from paleo proxy data are averages spanning the interval $6 \pm 0.5 \mathrm{ka}$. The corresponding $6 \mathrm{ka}$ average and the average for the last $3.5 \mathrm{ka}$ in MD95-2011 are 10.7 and $11.6^{\circ} \mathrm{C}$, respectively. A very important aspect of this comparison is that the $\mathrm{Mg} / \mathrm{Ca}$-based SST record from MD99-2251 was derived by analysis of $G$. bulloides. This species is generally regarded as being a near-surface living species that reproduce and calcify within the seasonal mixed-layer, hence the signal recorded by $G$. bulloides should be representative of the mixed-layer. The depth habitat of G. bulloides is confined to the upper $60 \mathrm{~m}$ of the water column at the location of MD992251 (Farmer et al., 2008, and references therein). Hence, the SST record from G. bulloides is expected to reflect SST changes in the near-surface environment of the core locality. This was used by Jansen et al. (2008) who proposed that the more surface-dwelling species, like G. bulloides, which normally calcify above the seasonal thermocline, would respond to changes in summer insolation and show the same Holocene SST trends as phytoplankton-based SST proxies with decreasing SSTs since the early and mid-Holocene. This is apparently not the case with the SSTs from core MD99-2251 (Fig. 8). Farmer et al. (2008) found it difficult to reconcile the near-surface depth habitat and summer season reproduction of $G$. bulloides with the theory that wintertime insolation changes should govern the long-term trends in their SST record. Farmer et al. (2008) pointed out that this reasoning implies a discrete separation between phyto- and zooplankton communities. Assuming that the $\mathrm{Mg} / \mathrm{Ca}$ record from MD99-2251 does reflect near-surface temperatures, the relatively cool $6 \mathrm{ka}$ SST temperature average registered at site MD99-2251 has to be interpreted as either significant lower surface summer temperatures in the mid-Holocene or a shift in the calcification/productivity season of G. bulloides (Farmer et al., 2008). Despite uncertainties in the productivity season of G. bulloides, significantly lower 6 ka SSTs during late spring/summer are difficult to reconcile with the negative 6 ka SST anomaly displayed by many North Atlantic phytoplankton records. A change in the timing and/or composition of the phytoplankton bloom is as another possible explanation. However, since the productivity of $G$. bulloides occurs during or shortly after phytoplankton bloom events (Farmer et al., 2008), a shift in timing of these events to earlier during spring or summer would result in a cooling in the G. bulloides as well as in the phytoplankton records if, for example, alkenone synthesizing Haptophycean species were involved.

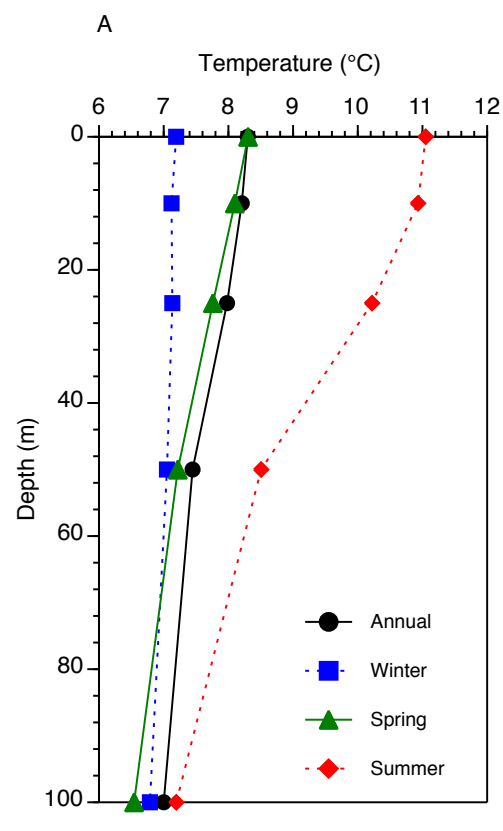

B
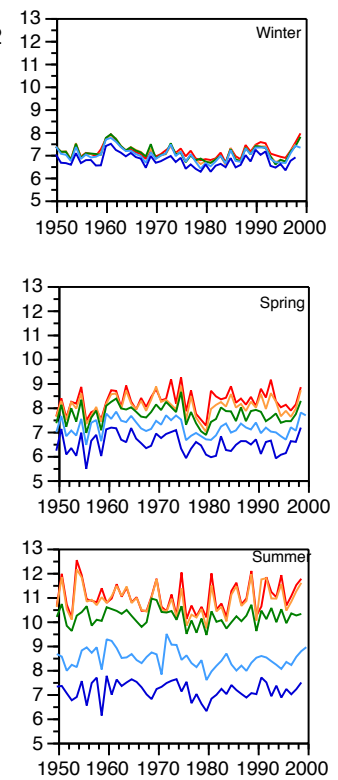

Fig. 7. (A) Seasonal and annual temperature averages for the last 50 years from Ocean Weather Station Mike in the upper $100 \mathrm{~m}$ of the water column. Averages are based on the temperature records presented in (B). From Nyland et al. (2006).

Other foraminifer temperature records from the subpolar North Atlantic, e.g. ODP 984 (Came et al., 2007) and RAPiD-12-1K (Thornalley et al., 2009) (Fig. 1) and NEAP 8K (Barker and Elderfield, 2002) (not shown), display the same lack of significant warmth in the early and mid-Holocene as the cores MD95-2011 and MD99-2251. $\mathrm{Mg} / \mathrm{Ca}$ temperature data from $G$. bulloides and $G$. inflata (RAPiD-12-1K) and N. pachyderma (dex) (ODP 984) are shown in Fig. 8 along with MD95-2011 and MD99-2251. The depth habitat of $G$. inflata is considerably deeper (base of seasonal thermocline) (Thornalley et al., 2009) compared to the depth habitats of G. bulloides and N. pachyderma. This discrepancy emphasizes the need to compare species with different depth habitat to fully be able to reconstruct changes in the upper water column. Long-term warming trends are apparent in all records based G. bulloides and N. pachyderma. In MD95-2011 and ODP 984 the increase in temperature seems to start around $8 \mathrm{ka}$ years ago, while in MD99-2251 and RAPiD-12-1K the trends of increasing warmth starts between 7-6 ka. There is also a marked shift in the mode of variability in all four records taking place around $4-3.5 \mathrm{ka}$ (Fig. 8). The $\mathrm{Mg} / \mathrm{Ca}$ temperature record from ODP 984 is significantly cooler compared to the other three records. However, this record is based on $\mathrm{Mg} / \mathrm{Ca}$ ratios in N. pachyderma (dex), which seems to have a calcification habitat at depth somewhere between the preferred depths of G. bulloides and N. pachyderma ( $\sin$ ) (see discussion above) and thus is expected to show somewhat cooler temperatures relative to G. bulloides. From the comparison between North 

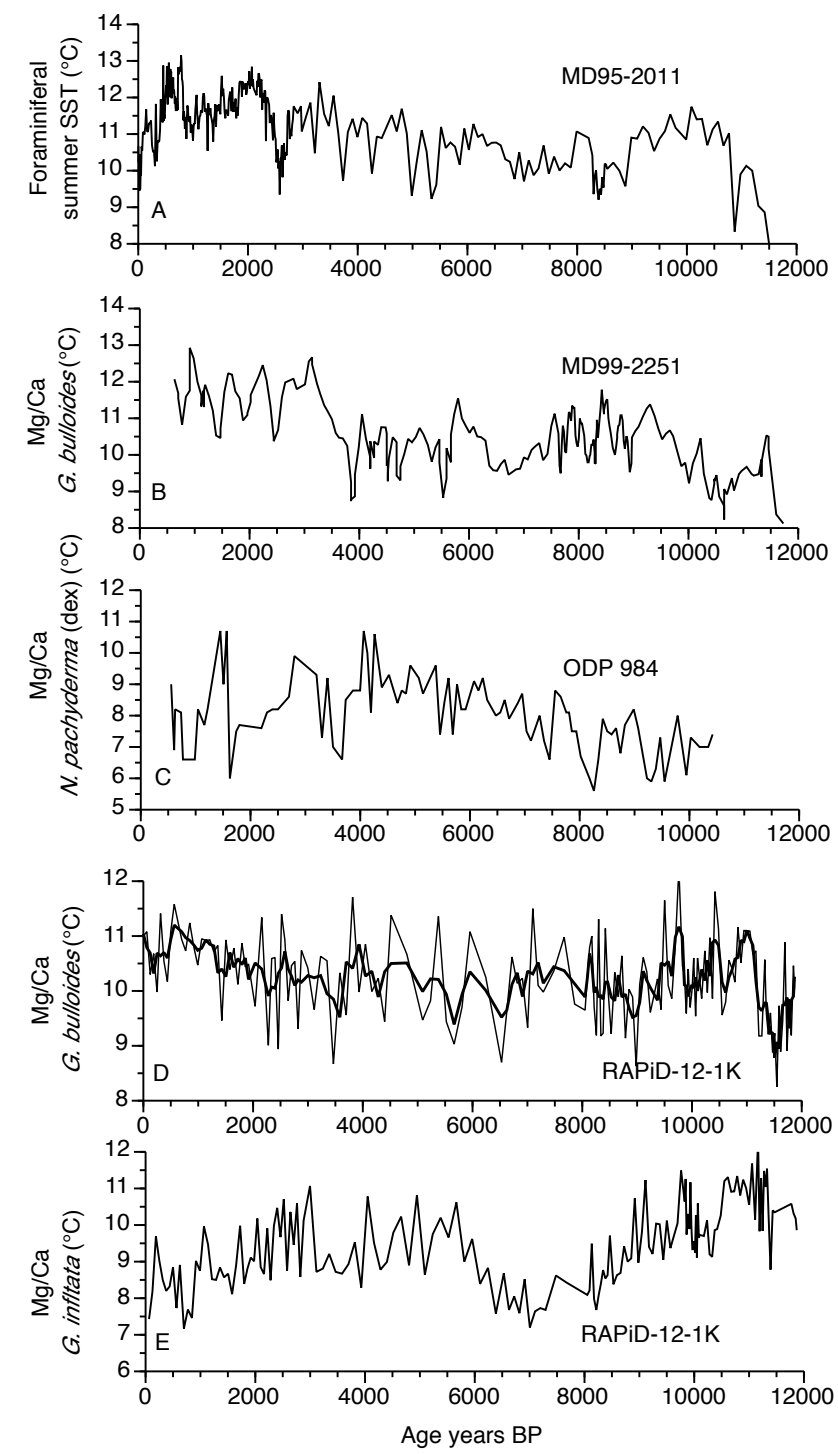

Fig. 8. Foraminiferal-based temperature records from the eastern Norwegian Sea and the northern North Atlantic south of Iceland. (A) Sea-surface temperature estimates for summer (JAS) for site MD95-2011 (Andersson et al., 2003; Risebrobakken et al., 2003; this study). (B) $\mathrm{Mg} / \mathrm{Ca}$ sea-surface temperatures for MD99-2251 based on G. bulloides (Farmer et al., 2008). (C) Mg/Ca sea-surface temperatures for ODP 984 based on $N$. pachyderma (dex) (Came et al., 2007). (D) $\mathrm{Mg} / \mathrm{Ca}$ sea-surface temperatures for RAPiD-12-1K based on G. bulloides (Thornalley et al., 2008). (E) $\mathrm{Mg} / \mathrm{Ca}$ seasurface temperatures for RAPiD-12-1K based on G. inflata (Thornalley et al., 2008).

Atlantic and Norwegian Sea foraminifer SST records, it is clear that they show no significant warmth during the early and mid-Holocene regardless of species or methods used to derive the SST records. With the existing data at hand it is not possible to rule out adaptations in species ecology, i.e. changes in depth habitat and/or shifts in seasonal productivity, at any of the sites discussed.
Farmer et al. (2008) concluded from comparisons between the Holocene trends in the Norwegian Sea and North Atlantic records that despite differences in the locations, proxy methods and species used, there seem to be a common climate linkage. All cores discussed in this study are located in the path of the NAC and its extension, and are to some extent expected to reflect changing properties of the inflowing relatively warm and saline waters throughout the Holocene as well as local changes in hydrography. Proposed theories to explain the records of the Nordic Seas include changes in atmospheric forcing (Risebrobakken et al., 2003), differences in ecology between zooplankton and phytoplankton combined with changes in the seasonality of the orbital forcing (Jansen et al., 2008) and stratification due to freshening (Hald et al., 2007). Moros et al. (2004) suggested that the increase in Northern Hemisphere winter insolation may have forced a mean annual temperature rise in the North Atlantic region, which could have led to stronger meriodional atmospheric circulation, especially after about $4 \mathrm{ka}$. More frequent and intense storm tracks would have led to relatively mild winters, a situation resembling the modern positive mode of the North Atlantic Oscillation (NAO) (Hurrell, 1995). In contrast, Risebrobakken et al. (2003) tied the increased influence of Arctic waters and stronger westerlies during the early and mid-Holocene, to northward shifts in the Icelandic Low and Atlantic jet stream, which may have an analogue in the modern mode of positive NAO. Model analyses do show a northward shift of the low-pressure system and jet stream in the Atlantic from glacial to present day-like climate (e.g. and Li and Battisti, 2008; Pausata et al., 2009). Comparisons between Holocene alkenone-based SST trends in the northeastern Atlantic and western subtropical Atlantic suggest a possible role for the NAO in generating millennial-scale SST trends and that these trends may be related to continuous weakening of a positive NAO pattern from the early to late Holocene (Rimbu et al., 2003). The model result for the midHolocene NAO suggests a small shift in mean state towards a more positive NAO regime compared to PI climate (Gladstone et al., 2005). This is in agreement with the pollen reconstructions (Davis et al., 2003) showing a more positive NAO regime during the mid-Holocene. This change can be interpreted as larger amplitude of the NAO variability with more time spent in a positive phase or there may also have been a shift in the mean state with no change in variability. However, proxy records with higher temporal resolution than those available are necessary in order to discriminate between possible changes in the character of the NAO.

At the two sites ODP 984 and RAPiD-12-1K salinity reconstructions are available for the Holocene (Came et al., 2007; Thornally et al., 2009). A freshening of both near-surface and sub-thermocline conditions is evident during the early Holocene, ending at around the $8.2 \mathrm{ka}$ event. Dinocyst estimates of sea-surface salinities from the Reykjanes Ridge and the Faroe-Shetland Channel documents lower sea-surface salinities before 6.5-7 ka BP than during 
the mid-late Holocene, suggesting dispersal of meltwater through the North Atlantic Current (Solignac et al., 2008). The records from ODP 984 and RAPiD-12-1K (based on $N$. pachyderma (dex) and G. bulloides, respectively) agree well and show a trend of increasing near-surface salinity since about 9-8 ka. Several previous studies from the northeastern and northwestern Atlantic, based on sea-surface salinity estimates from dinocysts, suggest a trend towards increasing surface salinities from mid to late Holocene (Solignac et al., 2004, 2006, and 2008; de Vernal and Hillaire-Marcel, 2006). Came et al. (2007) explains the Holocene trend of increasing temperature and salinity at Site 984 with a possible northward retreat of the boundary between polar and North Atlantic water. Thornalley et al. (2009) suggested that changes in salinity of the near-surface water were related to changes in the position of the subpolar front, at least on centennial to millennial time scales. Due to the proximity of the subpolar front to the southern Icelandic region it is likely that changes in the position of this front will affect the near-surface hydrography of the southern Icelandic sites (Thornalley, et al., 2009). Cooler and fresher subpolar waters would compete with water from the warmer and more saline NAC. However, the sub-termocline temperature and salinity records from RAPiD-12-1K, based on deep-dwelling $G$. inflata, display periods that were significantly warmer and more saline compared to the present. Thornalley et al. (2009) suggested that changes in relative contribution of waters drawn from the North Atlantic sub-polar gyre (SPG) and sub-tropical gyre (STG) could explain Holocene changes in sub-thermocline salinity and temperature south of Iceland. At present, the salinity of the Atlantic inflow is linked to the dynamics of the SPG on decadal time scales (Hátún et al., 2005). When the gyre circulation is strong the volume transport of relatively fresh and cool SPG water is high relative to the warm and saline water from the STG. High subthermocline salinities and temperatures in the NAC will then be the result of a weaker SPG circulation, which will allow a larger contribution of STG water to the NAC. Decadal scale variations in salinity of the Atlantic Ocean have been recorded over the past few decades (Curry et al., 2003; Hátún et al., 2005). Over the most recent decade positive salinities have been recorded in the inflow areas (Hátún et al., 2005). These changes are related to changes in the dynamics of SPG circulation, and have also been simulated using the Miami Isopycnal Coordinate Ocean Model (Hátún et al., 2005). At Selvogsbanki monitoring transect south of Iceland the mean spring 0-50 $\mathrm{m}$ temperature and salinity increased during the period 1990-2007 (Gislason et al., 2009). Furthermore, at OWS Mike a warming and increase in salinity has also been recorded over the past decade (Drange et al., 2005). These changes are likely to be related to changes in the dynamics of the SPG and STG gyres (S. Østerhus, personal communication, 2009). Moreover, at OWS Mike, it is clear that the temperature and salinity increase is recorded in the entire Atlantic water mass, also at near-surface depths of $50 \mathrm{~m}$.
Hence, on shorter time-scales changes in SPG dynamics are likely to be recorded by near-surface as well as sub-surface dwelling foraminifers. However, on millennial time-scale a decoupling between near-surface and sub-surface waters south of Iceland has been suggested and that the near-surface waters were influenced by a southward migration of subpolar waters rather than changes in the gyre dynamics (Thornalley et al., 2009). Recent results based on stable isotopes and dincysts on several sites in the North Atlantic clearly illustrate the large spatial and temporal heterogenities in the surface conditions in the North Atlantic (Solignac et al., 2004, 2006, 2008; de Vernal et al., 2006). Additional studies are needed to resolve how the dynamics of the SPG and STG influence the water column of the North Atlantic and Nordic Seas. Extensive use of proxy methods, such as $\mathrm{Mg} / \mathrm{Ca}$ ratios, able to reconstruct salinity for surface and sub-surface depths will be necessary.

The cause of the thermal maximum in the phytoplankton records were suggested by Jansen et al. (2008) to be related to radiative forcing alone. A possible increase in advection of North Atlantic waters into the Norwegian Sea was ruled out as the thickness of Atlantic water in this area is 400$600 \mathrm{~m}$ (Nilsen et al., 2008), and that the depth habitat of zooplankton may extend to a few hundred meters (Bé, 1977). Hence, an increase in advection would affect depths inhabited by both phytoplankton and zooplankton resulting in a positive anomaly in both plankton groups. However, this is apparently not the case.

\subsection{Modelling results versus data}

To further investigate the differences in trends between the Holocene phytoplankton and zooplankton records, the PMIP2/MOTIF modelling results for the mid-Holocene (6 ka) were taken into account (Braconnot et al., 2007). In this preliminary study we use the CCSM3 model results.

For the Norwegian Sea, the model generally shows positive $6 \mathrm{ka}$ sea-surface anomalies throughout the year, with a particularly pronounced anomaly during the summer season (Figs. 9, 10 and 11). This agrees well with the Holocene trends of estimated SSTs based on alkenones (Calvo et al., 2002; Jansen et al., 2008), and diatoms (Birks, 2000) (Fig. 6). The CCSM3 results indicate no or a negative $6 \mathrm{ka}$ anomaly at $100 \mathrm{~m}$ depth along the Norwegian coast, going from Skagerrak to Lofoten (Figs. 9, 10 and 11). The mid-Holocene modelled temperature depth profile for the Vøring Plateau (MD95-2011) is warmer at all depths for all seasons compared to PI values, except for a slightly cool anomaly between approximately 40-75 $\mathrm{m}$ water depth in summer (Fig. 12). By re-calibrating the foraminifer training data set using annual mean temperatures for $100 \mathrm{~m}$ water depth, the estimated $6 \mathrm{ka}$ annual $100 \mathrm{~m}$ foraminifer temperature for MD95-2011 is $6.8^{\circ} \mathrm{C}$, which is slightly cooler than both the corresponding modelled PI and $6 \mathrm{ka}$ temperature (Fig. 12). The resulting $6 \mathrm{ka} 100 \mathrm{~m}$ annual anomaly 
JAS

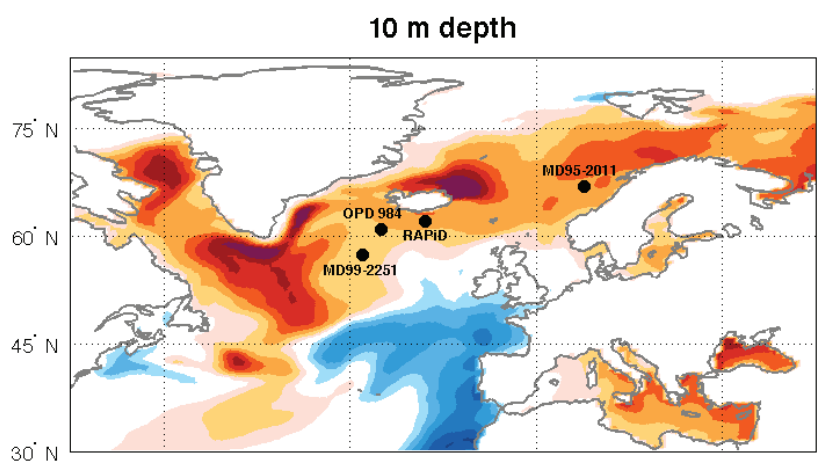

$100 \mathrm{~m}$ depth

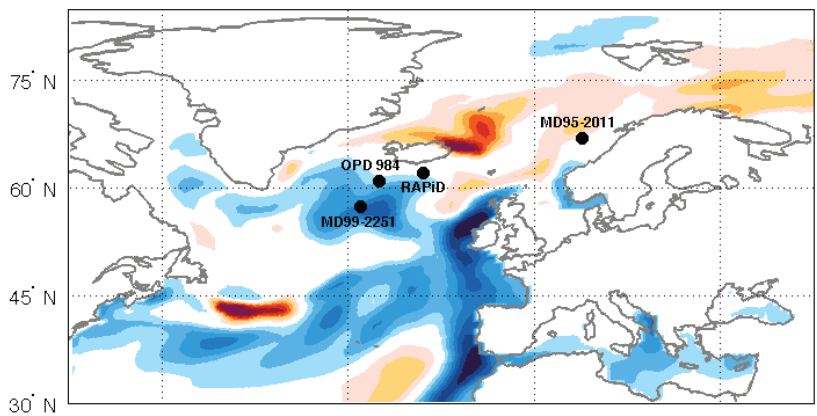

$100 m-10 m$
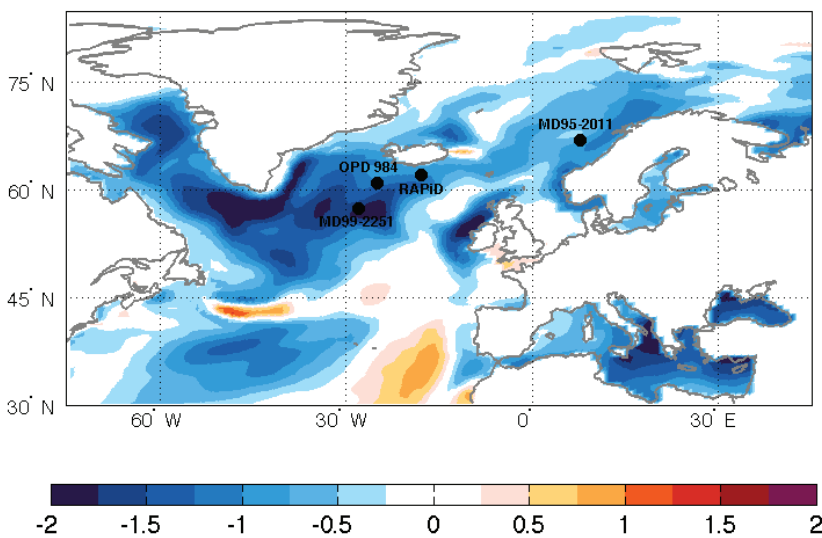

Fig. 9. Ocean potential temperature differences between $\mathrm{MH}$ and PI in CCSM3 for summer (JAS) at $10 \mathrm{~m}$ depth (upper panel) and $100 \mathrm{~m}$ depth (center). The lower panel shows the MH-PI anomaly for the difference between $100 \mathrm{~m}$ and $10 \mathrm{~m}$ depth.

(6 ka minus core top) for MD95-2011 is $-0.6^{\circ} \mathrm{C}$, whereas the modelled $100 \mathrm{~m}$ annual anomaly is $0 \pm 0.25^{\circ} \mathrm{C}$ (Fig. 11). Considering the uncertainties linked to both the faunal temperature estimates and the modelled temperatures, the model shows a fairly good agreement with the estimated temperature from MD95-2011.

For the area south of Iceland, where cores MD99-2251, ODP 984, and RAPiD-12-1K were retrieved, the model results indicate a strong positive summer temperature anomaly at the sea-surface between the mid-Holocene and PI period
JFM

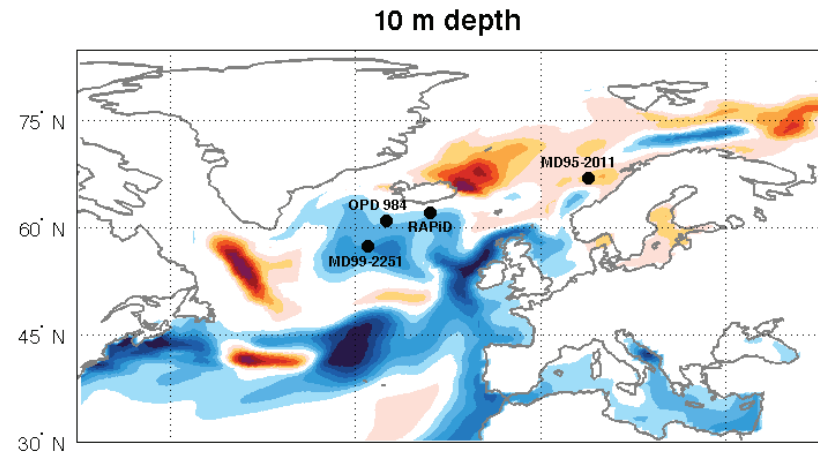

$100 \mathrm{~m}$ depth

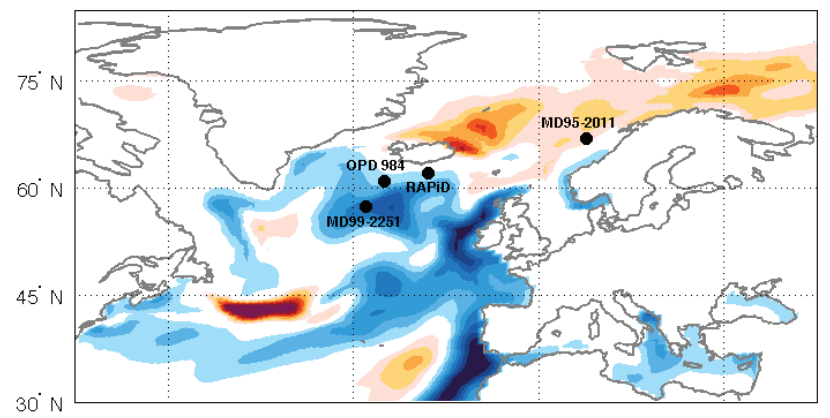

$100 m-10 m$

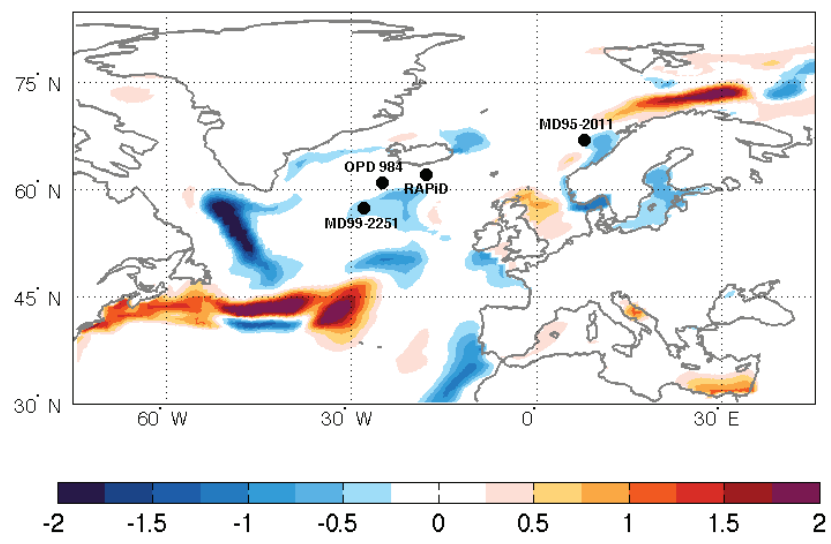

Fig. 10. 6k-0k CCSM3 model result for winter (JFM) temperature for $10 \mathrm{~m}$ and $100 \mathrm{~m}$ as well as the $6 \mathrm{k}-0 \mathrm{k}$ anomaly for the difference between $100 \mathrm{~m}$ and $10 \mathrm{~m}$.

(Figs. 9 and 12), whereas it is negative in winter (Fig. 10). At sub-surface depth the model shows a cooling throughout the year and Fig. 12 shows that the temperature is cooler compared to the PI for all sites south of Iceland at sub-surface depth for all seasons.Given the uncertainties in foraminifer depth habitats, the negative $6 \mathrm{ka}$ anomaly for sub-surface depths south of Iceland could explain the reconstructed temperature trends based on N. pachyderma (ODP 984). Calcification of $N$. pachyderma in the cooler sub-surface waters deeper than ca. $30 \mathrm{~m}$ (Fig. 12) would lead to the observed negative $6 \mathrm{ka}$ anomaly in the proxy data. To explain 


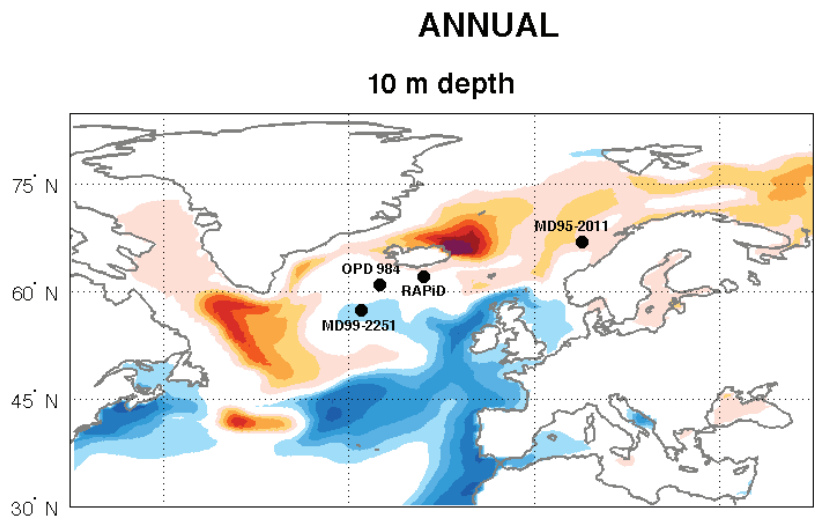

$100 \mathrm{~m}$ depth

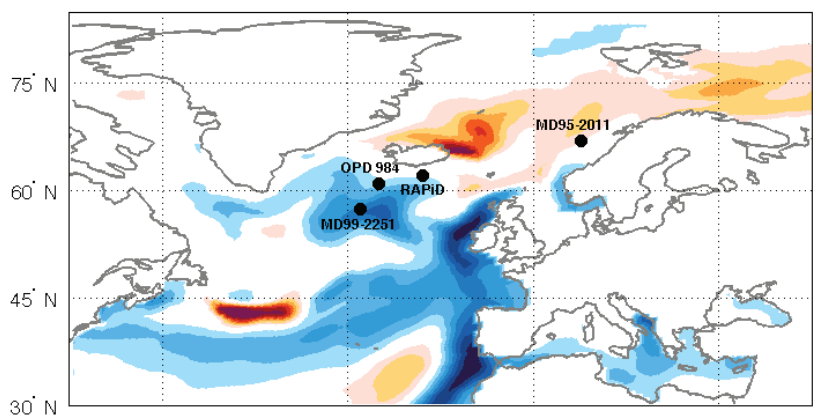

$100 m-10 m$
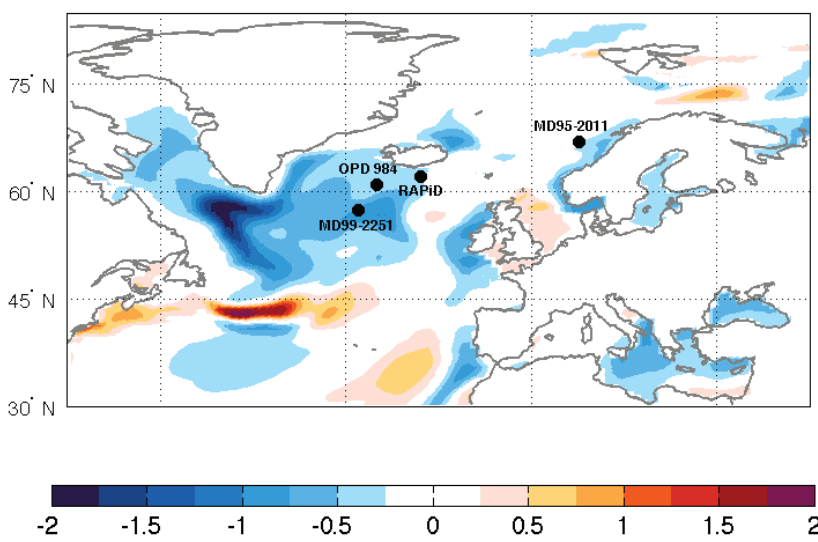

Fig. 11. 6k-0k CCSM3 model result for the annual mean temperature for $10 \mathrm{~m}$ and $100 \mathrm{~m}$ as well as the $6 \mathrm{k}-0 \mathrm{k}$ anomaly for the difference between $100 \mathrm{~m}$ and $0 \mathrm{~m}$.

the reconstructed temperature trends based on $G$. bulloides (MD99-2251, and RAPiD-12-1K) on the background of these modelling results, one may propose a somewhat deeper depth habitat for this species or advocate for a shift in productivity to earlier periods during summer or spring, as suggested by Farmer et al. (2008). However, the model results clearly show that the seasonal summer warming is restricted to the upper ca. $30 \mathrm{~m}$. Below $30 \mathrm{~m}$, the mid-Holocene temperature profile is cooler relative to the pre-industrial profile (Fig. 12). Schiebel et al. (1997) suggested that the reproduction of $G$. bulloides is mostly restricted to the upper
$60 \mathrm{~m}$ in the North Atlantic. Plankton tow results, with the majority of the samples collected in May, June and August, show that cytoplasma bearing tests of G. bulloides is present down to $300 \mathrm{~m}$, and that below $60 \mathrm{~m}(60-100 \mathrm{~m})$ the average number of G. bulloides tests per cubic meter is about half of that of the upper $60 \mathrm{~m}$ (Schiebel et al., 1997). The reconstructed cool mid-Holocene anomaly for MD99-2251 can be explained if we assume that the majority of the G. bulloides population reside below ca. $30 \mathrm{~m}$. If assuming a near-surface depth habitat of G. bulloides a shift in the productivity to cooler temperatures earlier during summer is only plausible if this is not linked to shifts in bloom involving a large fraction of the phytoplankton communities. For RAPiD-12-1K the shift between a warm $6 \mathrm{ka}$ anomaly at the surface to a negative $6 \mathrm{ka}$ anomaly at sub-surface depths takes place at about $75 \mathrm{~m}$ water depth (Fig. 12), which is slightly deeper relative to sites ODP 984 and MD99-2251. At RAPiD-12$1 \mathrm{~K}$ the $6 \mathrm{ka}$ cooling is also slightly less pronounced relative to the last 4-3.5 ka compared to MD99-2251 and MD952011 (Fig. 8). One scenario that could explain this is that $G$. bulloides at RAPiD-12-1K integrated a larger portion of the warmer surface waters during calcification. However, during the mid-Holocene the seasonal thermocline was more pronounced due to the increase in summer warming relative to at present. It is difficult to estimate the effect of this change on the depth habitat of planktic foraminifers, but it cannot be excluded that this may have had an effect on the preferred depth habitat.

The comparison between foraminifer-based temperature estimates and model results show that the Holocene trends in the proxy data can be explained by changes in hydrography at surface and sub-surface depths during the summer season. Modelling results indicate that while the seasonal summer warming of the sea-surface was stronger during the mid-Holocene, sub-surface depth experienced a cooling below 30-75 m (ODP 984, MD99-2251, and RAPiD-1-12K) or over a certain depth range (40-75 $\mathrm{m}$ at MD95-2011) (Fig. 12). This can explain the observed difference between the Holocene trends in phytoplankton and zooplankton temperature reconstructions. The sub-surface cool anomaly is registered at depth intervals occupied by both near-surface and deeper dwelling foraminifer species. There are no large differences in trend between reconstructions from nearsurface and deeper-dwelling foraminifer species, which is contrary to the suggestion by Jansen et al. (2008) that a cool mid-Holocene anomaly would be recorded by deeperdwelling species only. Our explanation does not exclude the possibility of smaller shifts in reproductive season (towards cooler months) or shifts in depth habitat (towards deeper depths), in addition to changes in hydrography, to explain the mid-Holocene anomaly in the proxy records. 

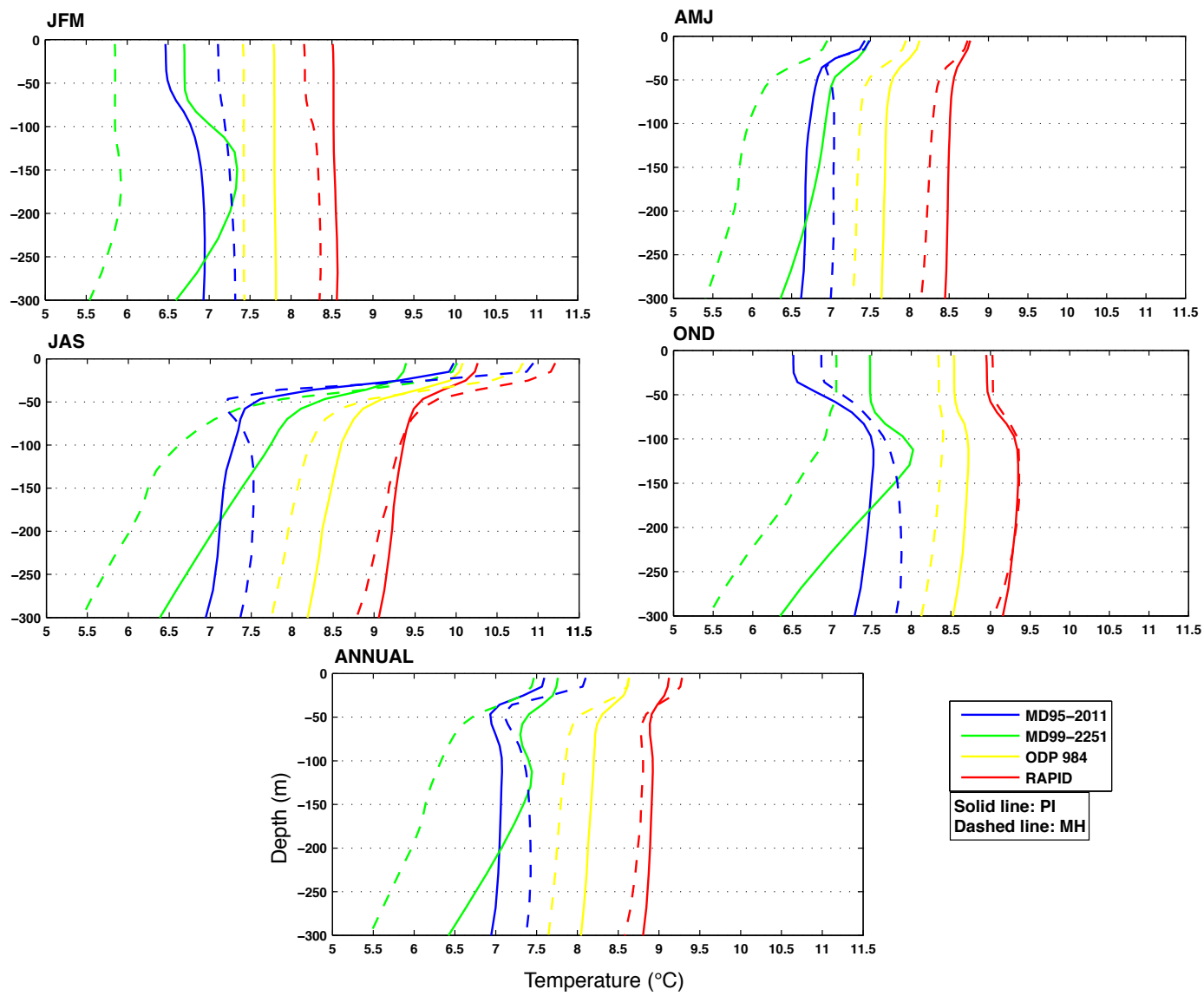

Fig. 12. Average annual and seasonal temperature profiles 0-300 m depth for site MD95-2011, MD99-2251, ODP 984, and RAPiD-12-1K from the CCSM3 model results.

\section{Conclusions}

Foraminifer temperature proxy records from the eastern Norwegian Sea (MD95-2011), and the North Atlantic south of Iceland (MD99-2251, ODP 984, and RAPiD-12$1 \mathrm{~K})$ show Holocene trends of increasing temperature from early/mid Holocene to late Holocene, in contrast to the early to mid-Holocene thermal maximum exhibited by many phytoplankton-based SST records (i.e. diatom and alkenone records). Based on comparisons between foraminifer temperature proxy data and CCSM3 model results the following results of local and regional importance are suggested:

1. Both records based on foraminifers with near-surface ( $G$. bulloides) and deeper dwelling ( $N$. pachyderma) habitat share the trend towards warmer late Holocene temperatures. The trend is also evident in records based on faunal assemblage changes as well as geochemical temperature proxies.

2. CCSM3 modelling results show a distinct $6 \mathrm{ka}$ summer (JAS) warming of the sea-surface in the North Atlantic and Norwegian Sea. Modelling results for the area south of Iceland suggests negative $6 \mathrm{ka}$ anomalies for all seasons but summer and for sub-surface depth $(100 \mathrm{~m})$ throughout the year. For the Norwegian Sea, the model generally shows positive $6 \mathrm{ka}$ sea-surface anomalies throughout the year, an anomaly that is particularly pronounced during the summer season.

3. Model summer temperature profiles for site MD992251, ODP 984, and RAPiD-12-1K display cool $6 \mathrm{ka}$ sub-surface anomalies. The strong summer warming appears to be restricted to the upper $30-75 \mathrm{~m}$. For site the MD95-2011, the model temperature profile exhibits a cool anomaly between 40-75 m water depth.

4. The relatively cool mid-Holocene foraminifer-based temperatures can be explained by the presences of cool sub-surface waters during summer (JAS). This explanation does not exclude the possibility of shifts in productivity season or changes in depth habitat between $6 \mathrm{ka}$ and the late Holocene. More extensive data-model comparisons are needed to test this hypothesis.

5. Several different suggestions have been made to explain the observed trends in the foraminifer records from the 
North Atlantic and Norwegian Sea. Changes in the dynamics of the subpolar gyre have recently been shown to have a great influence on the inflow of Atlantic water (Hátún et al., 2005). Changes in the supolar gyre circulation affect all the different branches of the Atlantic inflow, and could possibly be the common source of the temperature trends seen in the studied foraminifer records. However, the influence of the subpolar gyre circulation on the Atlantic inflow has only been examined on decadal time scales. Studies of proxy records with high temporal resolution are needed to examine how the dynamics of the subpolar gyre operates on longer time scales.

Acknowledgements. This work is a result of the EU funded MOTIF project, the Norwegian Research Council funded ARCTREC project as well as the workshop on Holocene climate variability over Scandinavia, hosted by the Bert Bolin Centre for Climate Research, Stockholm University, in April 2008. We acknowledge the international modelling groups for providing their data for analysis, the Laboratoire des Sciences du Climat et de l'Environnement (LSCE) for collecting and archiving the model data. The PMIP2/MOTIF Data Archive is supported by CEA, CNRS, the EU project MOTIF (EVK2-CT-2002-00153) and the Programme National d'Etude de la Dynamique du Climat (PNEDC). The analyses were performed using version 03-08-2007 of the database. More information is available on http://pmip2.lsce.ipsl.fr/ and http://motif.lsce.ipsl.fr/. This is publication nr. A240 of the Bjerknes Centre for Climate Research.

Edited by: H. Sundqvist

\section{References}

Abrantes, F.: Marine diatoms, in: Encyclopedia of Quaternary Science, edited by: Elias, S. A., Elsevier, 1668-1678, 2006.

Andersson, C., Risebrobakken, B., Jansen, E., and Dahl, S. O.: Late Holocene surface ocean conditions of the Norwegian Sea (Vøring Plateau), Paleoceanography, 18, 1044, doi:10.1029/2001pa000654, 2003.

Andersson C.: MOTIF North Atlantic database for foraminiferal based $6 \mathrm{k}$ sea-surface temperatures estimates, http://pmip2.1sce. ipsl.fr/synth/northatlantic6ksst.shtml, 2005.

Andersen, C., Koc, N., Jennings, A., and Andrews, J. T.: Nonuniform response of the major surface currents in the Nordic Seas to insolation forcing: Implications for the Holocene climate variability, Paleoceanography, 19, PA2003, doi:10.1029/2002PA000873, 2004.

Barker, S. and Elderfield, H.: Foraminiferal calcification response to glacial-interglacial changes in atmospheric CO2, Science, 297, 833-836, 2002.

Be', A. W. H.: An ecological, zoogeographic and taxonomic review of recent planktonic foraminifera, in Oceanic Micropaleontology Vol. 1, edited by Ramsay, A. T. S. E., Elsevier, New York, 1-100, 1977.
Berstad, I. M., Sejrup, H. P., Klitgaard-Kristensen, D., and Haflidason, H.: Variability in temperature and geometry of the Norwegian Current over the past $600 \mathrm{yr}$; stable isotope and grain size evidence from the Norwegian margin, J. Quaternary Sci., 18, 591-602, doi:10.1002/Jqs.790, 2003.

Birks, C. J. A. and Koc, N.: A high-resolution diatom record of lateQuaternary sea-surface temperatures and oceanographic conditions from the eastern Norwegian Sea, Boreas, 31, 323-344, 2002.

Blindheim, J., Borovkov, V., Hansen, B., Malmberg, S. A., Turrell, W. R., and Østerhus, S.: Upper layer cooling and freshening in the Norwegian Sea in relation to atmospheric forcing, Deep-Sea Res. Pt. I, 47, 655-680, 2000.

Braconnot, P., Otto-Bliesner, B., Harrison, S., Joussaume, S., Peterchmitt, J.-Y., Abe-Ouchi, A., Crucifix, M., Driesschaert, E., Fichefet, Th., Hewitt, C. D., Kageyama, M., Kitoh, A., Lan, A., Loutre, M.-F., Marti, O., Merkel, U., Ramstein, G., Valdes, P., Weber, S. L., Yu, Y., and Zhao, Y.: Results of PMIP2 coupled simulations of the Mid-Holocene and Last Glacial Maximum Part 1: experiments and large-scale features, Clim. Past, 3, 261277, 2007, http://www.clim-past.net/3/261/2007/.

Calvo, E., Grimalt, J. O., and Jansen, E.: High resolution $\mathrm{U}_{37}^{K}$ sea surface temperature reconstruction in the Norwegian Sea during the Holocene, Quaternary Sci. Rev., 21, 1385-1394, 2002.

Came, R. E., Oppo, D. W., and McManus, J. F.: Amplitude and timing of temperature and salinity variability in the subpolar North Atlantic over the past 10 k.y., Geology, 35, 315-318, doi:10.1130/G23455a.1, 2007.

Curry, R., Dickson, B., and Yashayaev, I.: A change in the freshwater balance of the Atlantic Ocean over the past four decades, Nature, 426, 826-829, doi:10.1038/Nature02206, 2003.

Darling, K. F., Kucera, M., Kroon, D., and Wade, C. M.: A resolution for the coiling direction paradox in Neogloboquadrina pachyderma, Paleoceanography, 21, PA2011, doi:10.1029/2005pa001189, 2006.

Davis, B. A. S., Brewer, S., Stevenson, A. C., Guiot, J., and Contributors, D.: The temperature of Europe during the Holocene reconstructed from pollen data, Quaternary Sci. Rev., 22, 17011716, doi:10.1016/S0277-3791(03)00173-2, 2003.

De Vernal., A. and Hillaire-Marcel, C.: Provincialism in trends an high frequency change in the northwest North Atlantic during the Holocene, Global Planet. Change, 54, 263-290, 2006.

Dolven, J. K., Cortese, G., and Bjørklund, K. R.: A highresolution radiolarian-derived paleotemperature record for the Late Pleistocene-Holocene in the Norwegian Sea, Paleoceanography, 17(4), 1072, doi:10.1029/2002PA000780, 2002.

Dowsett, H. J.: Planktic foraminifers, in: Encyclopedia of Quaternary Science, edited by: Elias, S. A., Elsevier, 1678-1682, 2006

Farmer, E. J., Chapman, M. R., and Andrews, J. E.: Centennialscale Holocene North Atlantic surface temperatures from $\mathrm{Mg} / \mathrm{Ca}$ ratios in Globigerina bulloides, Geochem. Geophys. Geosy., 9, Q12029, doi:10.1029/2008gc002199, 2008.

Flores, J.-A. and Sierro, F. J.: Coccoliths, in: Encyclopedia of Quaternary Science, edited by: Elias, S. A., Elsevier, 1634-1646, 2006.

Fraile, I., Mulitza, S., and Schulz, M.: Modeling planktonic foraminiferal seasonality: Implications for sea-surface temperature reconstructions, Mar. Micropaleontol., 72, 1-9, 2009. 
Gislason, A., Petursdottir, H., Astthorsson, O. S., Gudmundsson, K., and Valdimarsson, H.: Inter-annual variability in abundance and community structure of zooplankton south and north of Iceland in relation to environmental conditions in spring 1990-2007, J. Plankton Res., 31, 541-551, doi:10.1093/Plankt/Fbp007, 2009.

Gladstone, R. M., Ross, I., Valdes, P. J., Abe-Ouchi, A., Braconnot, P., Brewer, S., Kageyama, M., Kitoh, A., Legrande, A., Marti, O., Ohgaito, R., Otto-Bliesner, B., Peltier, W. R., and Vettoretti, G.: Mid-Holocene NAO: A PMIP2 model intercomparison, Geophys. Res. Lett., 32, L16707, doi:10.1029/2005g1023596, 2005.

Hald, M., Andersson, C., Ebbesen, H., Jansen, E., KlitgaardKristensen, D., Risebrobakken, L., Salomonsen, G. R., Sarnthein, M., Sejrup, H. P., and Telford, R. J.: Variations in temperature and extent of Atlantic Water in the northern North Atlantic during the Holocene, Quaternary Sci. Rev., 26, 3423-3440, doi:10.1016/J.Quascirev.2007.10.005, 2007.

Hátún, H., Sandø, A. B., Drange, H., Hansen, B., and Valdimarsson, H.: Influence of the Atlantic subpolar gyre on the thermohaline circulation, Science, 309, 1841-1844, doi:10.1126/Science.1114777, 2005.

Holland, M. M., Bitz, C. M., Hunke, E. C., Lipscomb, W. H., and Schramm, J. L.: Influence of the sea ice thickness distribution on polar climate in CCSM3, J. Climate, 19, 2398-2414, 2006.

Hurrell, J. W.: Decadal Trends in the North-Atlantic Oscillation - Regional Temperatures and Precipitation, Science, 269, 676679, 1995.

Jansen, E., Andersson, C., Moros, M., Nisancioglu, K. H., Nyland, B. F., and Telford, R. J.: 2008. The early to mid-Holocene thermal optimum in the North Atlantic, in: Natural Climate Variability and Global Warming - A Holocene Perspective, edited by: Battarbee, R. W. and Binney, H. A., Wiley-Blackwell, Chichester, 123-137, 2008.

Johannessen, T., Jansen, E., Flatøy, A., and Ravelo, A. C.: The relationship between surface water masses, oceanographic fronts and paleoclimatic proxies in surface sediments of the Greenland, Iceland and Norwegian Seas, in Carbon Cycling in the Glacial Ocean: Constraints on the Ocean's Role in Global Change, edited by: Zahn, R., Pedersen, T. F., Kaminski, M. A., and Labeyrie, L., Springer-Verlag, New York, 61-85, 1994.

Johannessen, T.: Stable isotopes as climate indicators in ocean and lake sediments, Ph.D. thesis, Dept. of Geol., Univ. of Bergen, Bergen, 1992.

Kaufman, D. S., Ager, T. A., Anderson, N. J., Anderson, P. M., Andrews, J. T., Bartlein, P. J., Brubaker, L. B., Coats, L. L., Cwynar, L. C., Duvall, M. L., Dyke, A. S., Edwards, M. E., Eisner, W. R., Gajewski, K., Geirsdottir, A., Hu, F. S., Jennings, A. E., Kaplan, M. R., Kerwin, M. N., Lozhkin, A. V., MacDonald, G. M., Miller, G. H., Mock, C. J., Oswald, W. W., Otto-Bliesner, B. L., Porinchu, D. F., Ruhland, K., Smol, J. P., Steig, E. J., and Wolfe, B. B.: Holocene thermal maximum in the western Arctic (0-180 degrees W), Quaternary Sci. Rev., 23, 529-560, doi:10.1016/J.Quascirev.2003.09.007, 2004.

Kim, J.-H. and Schneider, R. R.: GHOST global database for alkenone-derived 6ka sea-surface temperatures, online available: http://www.pangaea.de/Projects/GHOST/, 2004a.

Kim, J.-H. and Schneider, R. R.: GHOST global database for alkenone-derived Holocene sea-surface temperature records, online available: http://www.pangaea.de/Projects/GHOST/, 2004b.
Kim, J. H., Rimbu, N., Lorenz, S. J., Lohmann, G., Nam, S. I., Schouten, S., Rühlemann, C., and Schneider, R. R.: North Pacific and North Atlantic sea-surface temperature variability during the Holocene, Quaternary Sci. Rev., 23, 2141-2154, 2004c.

Kohfeld, K. E., Fairbanks, R. G., Smith, S. L., and Walsh, I. D.: Neogloboquadrina pachyderma (sinistral coiling) as paleoceanographic tracers in polar oceans: Evidence from northeast water Polynya plankton tows, sediment traps, and surface sediments, Paleoceanography, 11, 679-699, 1996.

Kucera, M., Rosell-Mele, A., Schneider, R., Waelbroeck, C., and Weinelt, M.: Multiproxy approach for the reconstruction of the glacial ocean surface (MARGO), Quaternary Sci. Rev., 24, 813819, doi:10.1016/J.Quascirev.2004.07.017, 2005.

Lazarus, D.: A brief review of radiolarian research, Palaeontol. Z., 79(1), 183-200, 2005.

Li, C. and Battisti, D. S.: Reduced Atlantic storminess during last glacial maximum: Evidence from a coupled climate model, J. Climate, 21, 3561-3579, doi:10.1175/2007jcli2166.1, 2008.

Liu, Z., Brady, E., and Lynch-Stieglitz, J.: Global ocean response to orbital forcing in the Holocene, Paleoceanography, 18, 1041, doi:10.1029/2002PA000819, 2003.

Lorenz, S. J., Kim, J. H., Rimbu, N., Schneider, R. R., and Lohmann, G.: Orbitally driven insolation forcing on Holocene climate trends: Evidence from alkenone data and climate modeling, Paleoceanography, 21, PA1002, doi:10.1029/2005PA001152, 2006.

Macdonald, G. H.: Some Holocene palaeoclimatic and palaeoenvironmental perspectives on Arctic/Subarctic climate warming and the IPCC 4th Assessment Report, J. Quaternary Sci., 25(1), 3947, 2010.

Marchal, O., Cacho, I., Stocker, T. F., Grimalt, J. O., Calvo, E., Martrat, B., Shackleton, N., Vautravers, M., Cortijo, E., van Kreveld, S., Andersson, C., Koc, N., Chapman, M., Sbaffi, L., Duplessy, J. C., Sarnthein, M., Turon, J. L., Duprat, J., and Jansen, E.: Apparent long-term cooling of the sea surface in the northeast Atlantic and Mediterranean during the Holocene, Quaternary Sci. Rev., 21, 455-483, 2002.

Meehl, G. A., Washington, W. M., Santer, B. D., Collins, W. D., Arblaster, J. M., Hu, A. X., Lawrence, D. M., Teng, H. Y., Buja, L. E., and Strand, W. G.: Climate change projections for the twentyfirst century and climate change commitment in the CCSM3, J. Climate, 19, 2597-2616, 2006.

Moros, M., Emeis, K., Risebrobakken, B., Snowball, I., Kuijpers, A., McManus, J., and Jansen, E.: Sea surface temperatures and ice rafting in the Holocene North Atlantic: climate influences on Northern Europe and Greenland, Quaternary Sci. Rev., 23, 2113-2126, doi:10.1016/J.Quascirev.2004.08.003, 2004.

Nilsen, J. E. Ø., Hátún, H., Mork, K. A., and Valdimarsson, H.: The NISE Dataset. Tech. Rep. 08-01. Faroese Fisheries Laboratory, Box 3051, Tórshavn, Faroe Islands, 17 pp., 2008.

Nyland, B. F., Jansen, E., Elderfield, H., and Andersson, C.: Neogloboquadrina pachyderma (dex. and sin.) $\mathrm{Mg} / \mathrm{Ca}$ and delta O-18 records from the Norwegian Sea, Geochem. Geophy. Geosy., 7, Q10P17, doi:10.1029/2005GC001055, 2006.

Østerhus, S., Gammelsrød, T. and Hogstad, R.: Ocean Weather Ship Station $\mathrm{M}\left(66^{\circ} \mathrm{N}, 2^{\circ} \mathrm{E}\right)$ : The longest existing homogenous time series from the deep ocean, WOCE Newsletter, 24/96, Southampton Oceanographic. Center, Univ. of Southampton, Southampton, UK, 1996. 
Osterman, D., Curry, W. B., Honjo, S., Olafsson, J., and Manganini, S. J.: Variability of Foraminiferal Flux and Isotopic Composition at Sites Around Iceland and the Sea of Okhotsk, with a Special Focus on N. pachyderma (sinistral and dextral), G. quinqueloba and $G$. bulloides, 6th International Conference on Paleoceanography, August 1999, Lisboa, Portugal, 1999.

Ottens, J. J.: Planktic foraminifera in the Northeast Atlantic. Ph.D. Thesis, Planktic foraminifera as indicators of ocean environments in the Northeast Atlantic, Enschede, 89 pp., 1992.

Pausata, F. S. R., Li, C., Wettstein, J. J., Nisancioglu, K. H., and Battisti, D. S.: Changes in atmospheric variability in a glacial climate and the impacts on proxy data: a model intercomparison, Clim. Past, 5, 489-502, 2009, http://www.clim-past.net/5/489/2009/.

Renssen, H., Seppa, H., Heiri, O., Roche, D. M., Goosse, H., and Fichefet, T.: The spatial and temporal complexity of the Holocene thermal maximum, Nat. Geosci., 2, 410-413, doi:10.1038/Ngeo513, 2009.

Rimbu, N., Lohmann, G., Kim, J. H., Arz, H. W., and Schneider, R.: Arctic/North Atlantic Oscillation signature in Holocene sea surface temperature trends as obtained from alkenone data, Geophys. Res. Lett., 30, 1280, doi:10.1029/2002GL016570, 2003.

Risebrobakken, B., Jansen, E., Andersson, C., Mjelde, E., and Hevrøy, K.: A high-resolution study of Holocene paleoclimatic and paleoceanographic changes in the Nordic Seas, Paleoceanography, 18, 1017, doi:10.1029/2002pa000764, 2003.

Schiebel, R., Bijma, J., and Hemleben, C.: Population dynamics of the planktic foraminifer Globigerina bulloides from the eastern North Atlantic, Deep-Sea Res. Pt. I, 44, 1701-1713, 1997.

Seppä, H. and Birks, H. J. B.: July mean temperature and annual precipitation trends during the Holocene in the Fennoscandian tree-line area: pollen-based climate reconstructions, Holocene, 11, 527-539, 2001.

Simstich, J., Sarnthein, M., and Erlenkeuser, H.: Paired delta O18 signals of Neogloboquadrina pachyderma (s) and Turborotalita quinqueloba show thermal stratification structure in Nordic Seas, Mar. Micropaleontol., 48, 107-125, doi:10.1016/S03778398(02)00165-2, 2003.
Smith, R. D. and Gent, P. R.: Reference manual for the Parallel Ocean Program (POP): Ocean Component of the Community Climate System Model (CCSM2.0 and CCSM3.0). Los Alamos National Laboratory Technical Report LA-UR-02-2484, 2004. Available from: http://www.ccsm.ucar.edu/models/ccsm3.0/pop, 2004.

Solignac, S., de Vernal, A., and Hillaire-Marcel, C.: Holocene seasurface conditions in the North Atlantic - contrasted trends and regimes in the western and eastern sectors (Labrador Sea vs. Iceland Basin), Quaternary Sci. Rev., 23(3-4), 319-334, 2004.

Solignac, S., Giraudeau, J., and de Vernal, A.: Holocene sea surface conditions in the western North Atlantic: Spatial and temporal heterogeneities, Paleoceanography, 21(2), PA2004, doi:10.1029/2005PA001175, 2006.

Solignac, S., Greland, M., de Vernal, A., Giraudeau, J., Moros, M., McCave, I.N., and Hoogaker, B: Reorganization of the upper ocean circulation in the mid-Holocene in the northeastern Atlantic, Can. J. Earth Sci., 45, 1417-1433, 2008.

ter Braak, C. J. F. and van Dam, H.: Inferring pH from diatoms: a comparison of old and new calibration methods, Hydrobiologia, 178, 209-223, 1989.

ter Braak, C. J. F. and Looman C. W. N.: Weighted averaging, logistic-regression and the Gaussian response model, Vegetatio, 65, 3-11, 1986

ter Braak, C. J. F. and Prentice, I. C.: A theory of gradient analysis, Adv. Ecol. Res., 18, 271-317, 1988.

Thornalley, D. J. R.: Palaeoceanography of the South Iceland Rise over the past 21,000 years, PhD Thesis, Cambridge, 2008.

Thornalley, D. J. R., Elderfield, H., and McCave, I. N.: Holocene oscillations in temperature and salinity of the surface subpolar North Atlantic, Nature, 457, 711-714, doi:10.1038/Nature07717, 2009.

World Ocean Atlas: Tech. rep., National Oceanographic Data Center, Silver Spring, Maryland, http://www.esrl.noaa.gov/psd/, Version 2, 1998. 